\title{
Indukált pluripotens őssejtek szerepe a neurológiai betegségek modellezésében
}

\author{
Balogh Zoltán ${ }^{1,2}$ - Réthelyi János dr., ${ }^{3,4}$ Molnár Mária Judit dr. ${ }^{2}$ \\ Semmelweis Egyetem, Általános Orvostudományi Kar, 'Szentágothai János Idegtudományi Doktori Iskola, \\ ${ }^{2}$ Genomikai Medicina és Ritka Betegségek Intézete, ${ }^{3}$ Pszichiátriai és Pszichoterápiás Klinika, Budapest \\ ${ }^{4}$ MTA-SE-NAP B Molekuláris Pszichiátriai Kutatócsoport, Budapest
}

\begin{abstract}
A központi idegrendszert érintő betegségek kialakulásának és lefolyásának molekuláris szintű longitudinális nyomon követése évtizedekig nem volt megoldott, a kóros állapotú szerv vagy szövet direkt vizsgálatára általában a betegség késői stádiumában volt lehetőség. A központi idegrendszeri betegségek modellezése jelentős szerepet játszik az egyes kórképek patomechanizmusának megismerésében, azonban az állatmodellek alkalmazása a fajok idegrendszerei között fennálló különbségek miatt a levont következtetések érvényességét, a transzlációt nagymértékben gyengítik. Az ily módon felmerülő problémák részbeni áthidalására lehet alkalmas az indukált pluripotens őssejtek nyújtotta modell, amely az utóbbi években jelentősen hozzájárult a neurodegeneratív és neurodevelopmentális betegségek patogenezisének megértéséhez. Az indukált pluripotens őssejtek a klinikai vizsgálatok előkészítése során még háttérbe szorulnak, azonban a sejtélettani és molekuláris biológiai mechanizmusok tanulmányozásában már ma kiemelkedő szerepük van. Orv. Hetil., 2015, 156(26), 1035-1039.
\end{abstract}

Kulcsszavak: indukált pluripotens őssejt, központi idegrendszeri megbetegedések, transzlációs kutatások

\section{The role of induced pluripotent stem cells in neurological disease modeling}

The longitudinal follow-up of the development and course of central nervous system related diseases on a molecular level was unsolved for decades. Direct examination of the pathological state on organ or tissue levels was feasible in the late stage of the disease. Modeling diseases has an important role in studying the pathophysiological mechanism underlying central nervous system disorders but animals used as model organism due to species specific nervous system differences can lead to less valid conclusions in translational research. The model of induced pluripotent stem cells may help to solve partially these types of problems. In recent years this model had a strong effect on understanding the pathogenesis of neurodegenerative and neurodevelopmental disorders. Although induced pluripotent stem cells have a low impact on clinical research studies, they have a prominent role in the field of cell physiology and molecular biology research.

Keywords: induced pluripotent stem cells, central nervous system diseases, translational research

Balogh, Z., Réthelyi, J., Molnár, M. J. [The role of induced pluripotent stem cells in neurological disease modeling]. Orv. Hetil., 2015, 156(26), 1035-1039.

(Beérkezett: 2015. március 27.; elfogadva: 2015. április 23.)

\section{Rövidítések}

ALS = amyotrophiás lateralsclerosis; APP $=$ amyloid prekurzor protein; CDKL5 = cyclin-dependent kinase-like 5; DYRKIA = tyrosine- $(\mathrm{Y})$-phosphorylation regulated kinase $1 \mathrm{~A}$; $\mathrm{FMRl}=$ fragilis $\mathrm{X}$ mentális retardáció $\mathrm{l} ; \mathrm{FMRP}=$ fragilis $\mathrm{X}$ mentális retardáció protein; ICTRP = nemzetközi klinikai vizsgálatok regisztrációs felülete; IGF-1 = inzulinszerű növekedési faktor 1 ; iPS-sejtek = indukált pluripotens őssejtek; iPSC-modell $=$ indukált pluripotens őssejt modell; MECP2 = metilCpG-kötő protein 2; WHO = Egészségügyi Világszervezet
A központi idegrendszert érintő neurológiai megbetegedések mögött álló fiziológiai és molekuláris okok felderítése klasszikusan post mortem szövetminták vizsgálatán alapult. A betegségek kialakulásának, lefolyásának molekuláris szintü longitudinális nyomon követése azonban ez esetben nem megfelelően megoldott, a beteg szerv vagy szövet direkt vizsgálata csupán a betegség végső stádiumáról nyújt információkat. A progresszív lefolyású neurodegeneratív kórképek vagy egyéb központi ideg- 
rendszeri patológiás folyamatok okainak beható felderítése hosszú távú megfigyeléseket igényel, így a betegség sikeres modellezésének jelentős szerepe lehet a kérdéses mechanizmusok molekuláris hátterének feltárásában. Az ily módon felmerülő problémák részbeni megoldására lehet alkalmas az indukált pluripotens őssejtek (iPS-sejtek) nyújtotta modell $[1,2]$.

\section{Modelltöl modellig}

A neurológiai kórképek megismerésében jelentős segítséget nyújt a kutatók számára az állatmodellek alkalmazása. E modellekben transzgenikus, illetve knock-out egyedeket alkalmaznak a patológiás elváltozások megismerésére $[3,4]$. Az állatmodellek - vitathatatlan eredményein túl - azonban legkielégítőbben monogénes rendellenességek vizsgálatára alkalmazhatóak, amelyek csupán a betegségek egy hányadát fedik le. Számos esetben a komplexebb idegrendszeri funkciók vizsgálatánál a fajok közötti különbségek a levont következtetések érvényességét, transzlációját gyengítik a humán betegségekre nézve. A helyzetet tovább árnyalja a számos, az állatkísérletekben jól teljesítő farmakon preklinikai vizsgálatok során bekövetkező kudarca [4, 5]. Utóbbi rendkívüli mértékben terheli a gyógyszeripart, egy hatóanyag piacra kerülése becslések szerint 900 millió amerikai dollárt is felemészthet [6].

E nehézségek részbeni feloldására és a sejtszintû patológiás folyamatok jobb megismerésére lehet alkalmas az indukált pluripotens őssejtek nyújtotta modell. A pluripotens státusú sejtek létrehozása szomatikus sejtekból egészen 2006-ig megoldatlan volt. Takahashi és Yamanaka mutatta meg elsőként, milyen módszerrel lehetséges szomatikus sejteket pluripotens állapotba hozni négy gén (Sox2, Klf4, Oct3/4, c-Myc) segítségével $[7,8]$. E módszerrel a sejtek valóban pluripotens állapotba hozhatóak, az embrionális őssejtekhez hasonlóan e szomatikus eredetü, indukált pluripotens őssejtek is idegsejtté, szívizomsejtté vagy bármely, az embrionális csíralemezekből származó sejttípussá differenciáltathatóak a szükséges faktorok alkalmazásával $[9,10,11]$. Így a humán testi sejtekből származó indukált pluripotens őssejtek felhasználásával, azok neuronalis irányba történő differenciáltatásával a központi idegrendszert kialakító sejtek, sejtvonalak hozhatóak létre. E sejtvonalak segítséget nyújtanak a központi idegrendszert érintő neurológiai betegségek vizsgálatában, hisz a betegség kialakulásához vezető mutációkat, illetve fenotípust hordozzák [12, 13].

$\mathrm{Az}$ iPS-sejtek nyújtotta modell jelentőségét tovább növeli a központi idegrendszeri betegségekben érintettek rendkívül nagy száma. 2005-ben hozzávetőlegesen 24,3 millió beteg szenvedett a demencia valamely formájában, ez az érték, a becslések szerint, 2040-re elérheti a 81,1 milliót [14]. Az Egyesült Államokban hozzávetőlegesen 7 millió ember szenved valamely neurodegeneratív betegségben, jelentős hányaduk, mintegy 5,3 millió fó érintett Alzheimer-kórban [15]. A betegek száma a vár- ható élettartam-növekedéssel tovább emelkedhet, ismert hatásos gyógymód hiányában egyre jelentősebb társadalmi és gazdasági problémát jelentve a jövő generációi számára. Bioetikai, orvosi etikai szempontból az embrionális össejtekhez viszonyítva az iPS-sejteken alapuló technikák alkalmazása kevesebb problémát vet fel, még ha nem is teljességgel problémamentes [16].

\section{Neurodegeneratin, neurodevelopmentális, neurogenetikai betegségek és kromoszóma- rendellenességek modellezése}

2006-ot követően az iPS-sejtek segítségével megindult a betegségek modellezése, amely a korábbi években elsősorban embrionális őssejtekkel zajlott. A kutatások neurodegeneratív, neurodevelopmentális és egyéb neurogenetikai betegségekre és kromoszóma-rendellenességekre széleskörüen kiterjedtek.

Az időskori demencia egyik leggyakoribb okaként számon tartott Alzheimer-kór modellezésében Mason A. Israel és munkatársai mutatták meg, miként hasonlítható össze a megbetegedés familiáris és sporadikus megjelenése. Alzheimer-kórban szenvedő betegektől származó fibroblastsejtekből állítottak elő iPS-sejteket, amelyeket neuronokká differenciáltattak. A betegségre jellemző patológiás fenotípus jelent meg in vitro, a kóros sejtélettani folyamatok mérhetóvé váltak [17]. Az Alzheimer-kórhoz hasonlóan nagy társadalmi terhet képviselő neurodegeneratív megbetegedés, a Parkinson-kór modellezéséhez dopaminerg neuronokat hoztak létre pluripotens sejtek felhasználásával. A módszer alkalmazása az egyes terápiás ágensek vizsgálatán túl a parkin gén sejtélettani funkciójának alaposabb megismeréséhez is hozzájárult, amely szerint a gén terméke szerepet játszik az idegsejtek komplex morfológiájának kialakításában a microtubularis rendszer stabilizálásán keresztül $[18,19]$.

Egy másik nem túl ritka autoszomális domináns neurodegeneratív betegség, a Huntington-kór oka a huntingtin fehérjét kódoló génben található polimorf trinukleotid ismétlődés kóros expanziója. A Huntington-kórban szenvedő betegek fibroblastsejtjeiből előállított iPS-sejtekben homológ rekombinációval sikerült a kóros ismétlődésszámot normalizálni, ezáltal a sejtek kóros fenotípusát megszüntetni [20]. A normalizált trinukleotid ismétlődésszám a pluripotens sejtek neuronná való differenciálása után is fennmaradt.

$\mathrm{Az}$ autizmus spektrumbetegség egyik jól ismert monogénesen öröklődő tagja a Rett-szindróma, amelyért a MECP2 (metil-CpG-kötő protein 2) gén mutációja tehető felelőssé [21]. A betegektôl származó fibroblasteredetű iPS-sejtekből differenciáltatott idegsejteken is sikerült igazolni maturációs defektusokat. A mutáns gént hordozó idegsejtek kevesebb szinapszist hoznak létre, a dendrittüskék száma kevesebb, és jellegzetes elektrofiziológiai rendellenességeket mutatnak. Feltétezhető, hogy e sejtek alkotta hálózat nem képes kielégítően informá- 
ciófogadásra, valamint -továbbításra és ezáltal járul hozzá a neurodevelopmentális kórkép megjelenéséhez [22]. Szintén iPS-sejtek segítségével vizsgálták a CDKL5 (cyclin-dependent kinase-like 5) gént érintó mutáció és az IGF-1 (inzulinszerü növekedési faktor 1) szerepét a Rett-szindróma patofiziológiájában [23, 24].

A fragilis X-szindróma - mint az egyik leggyakoribb örökletes, mentális retardációt okozó genetikai betegség - hátterében az FMRI (fragilis X mentális retardáció $\mathrm{l}$ ) gén 5 ' nem átíródó régiójában levô kóros CGG-trinukleotid-ismétlődés expanziója áll [25]. A fragilis X-szindrómában szenvedő betegek fibroblastjaiból differenciáltatott iPS-sejtek vizsgálata során az FMRl gén metilált maradt, így transzkripciósan inaktívvá vált [26]. Annak ellenére, hogy eleinte úgy tûnt, nem lesz alkalmas az iPSC-modell a szindróma modellezésére, egy évvel később Sheridannek és munkatársainak epigenetikai megközelítéssel sikerült az FMRP (fragilis X mentális retardáció protein) fontosságát az idegrendszer korai fejlődésében (elsősorban a szinaptogenezisben) igazolni [27].

A Down-szindróma a 21. kromoszóma triszómiája által okozott, jól ismert kórkép [28]. Azt azonban, hogy a 21-es kromoszómán helyet foglaló APP (amyloid prekurzor protein) expressziós aktivitása a szokottnál magasabb a Down-szindrómás betegekben, és így az Alzheimer-kór korai állapotára jellemző celluláris folyamatok figyelhetőek meg esetükben, csak az iPS-sejtek nyújtotta lehetôségekkel volt bizonyítható [29]. A betegek testi sejtjeiből differenciáltatott iPS-sejteken figyelték meg, hogy az Alzheimer-kórra jellemzô sejtszintú patológiás elváltozások néhány hónap alatt megjelentek in vitro, az elóállított idegsejtekben amyloidaggregátumok halmozódtak fel. Az iPSC-modell segítségével sikerült megismerni a DYRKIA - tyrosine-(Y)-phosphorylation regulated kinase 1A - szerepét is Down-szindrómában [30].

$\mathrm{Az}$ amyotrophiás lateralsclerosis (ALS) vagy más néven Lou Gehrig-betegség patofiziológiai alapjainak felismerését is előremozdították az in vitro vizsgálatok. Eddig számos gén mutációját hozták összefüggésbe az ALS-sel $[31,32]$. Az egyes génhibáknak megfelelően többféle iPS-sejtvonal létrehozására is sor került annak érdekében, hogy a mutációk molekuláris szerepét pontosítsák és a betegség kezelésére alkalmas terápiás célpontokat azonosíthassanak $[33,34,35]$.

Az említett megbetegedések a jéghegy csúcsát jelentik, a központi idegrendszert érintő szinte valamennyi megbetegedés őssejtekkel történő modellezése folyamatban van. Az iPSC-modellnek köszönhetően a kóros elváltozások mögött álló sejtélettani folyamatokat egyre behatóbban ismerjük meg.

\section{Klinikai vizsgálatok ôssejtek segitségével}

Vizsgálatok folynak a sclerosis multiplex, a stroke, a gerincvelö-sérülés, az ALS, a cerebralis paresis, a traumás agysérülés, a diabeteses neuropathia, a cerebellaris ataxia,

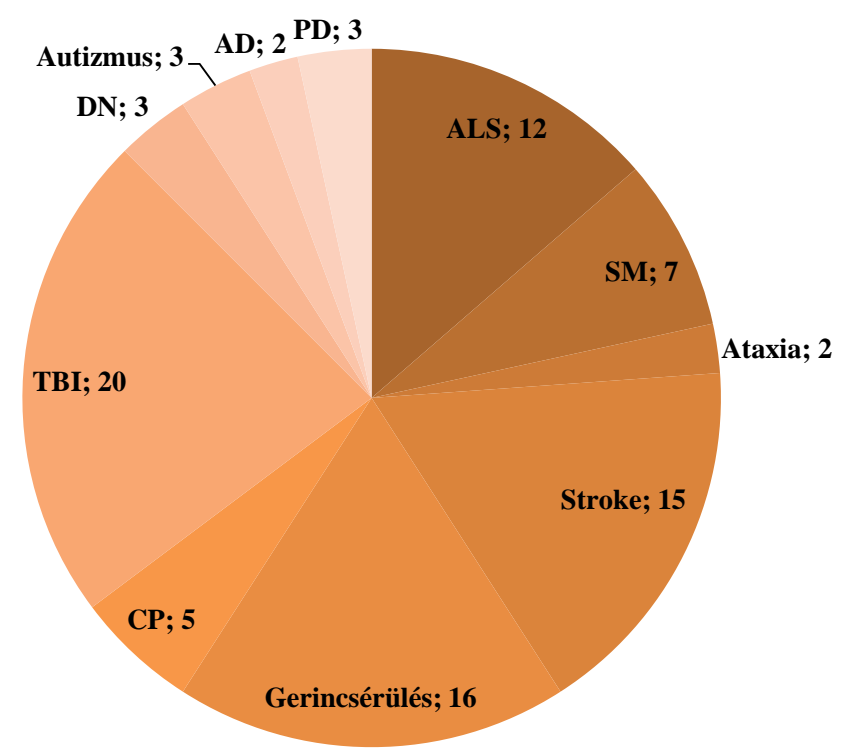

1. ábra A WHO ICTRP (International Clinical Trials Registry Platform
- http://www.who.int/ictrp) adatbázisába az elmúlt 3 évben
bekerült őssejtalapú kezeléssel foglalkozó klinikai vizsgálatok
száma (db) betegségenként az adatbázis 2015. január 12-ei állá-
sa szerint
AD = Alzheimer-kór; ALS = amyotrophiás lateralsclerosis;
$\mathrm{CP}=$ cerebralis paresis; DN = diabeteses neuropathia; PD = Par-
kinson-kór; SM = sclerosis multiplex; TBI = traumás agysérülés

az autizmus, az Alzheimer-, illetve a Parkinson-kór kezelésének területén. Az Egészségügyi Világszervezet (WHO) nemzetközi klinikai vizsgálatokat gyújtő regiszterét (ICTRP - International Clinical Trials Registry Platform) alapul véve a traumás agysérülés, a gerincsérülés és a stroke jelentik a klinikai vizsgálatok forró pontjait (1. ábra). E vizsgálati státusba jutott őssejteken alapuló kezelési módok esetén döntően a szöveti őssejtek alkalmazása jellemző. Míg a laboratóriumokban az indukált pluripotens őssejteken történő vizsgálatok megvetették lábukat, addig a klinikai vizsgálatok során ez jelenleg nem figyelhető meg.

\section{Következtetések}

Az indukált pluripotens őssejtek nyújtotta modellben a számos előny mellett az in vitro sejttechnológiák minden hátránya is megjelenik. Ezzel magyarázható talán, hogy a klinikai vizsgálati fázisba jutott terápiák esetében háttérbe szorultak. A sejtélettani és molekuláris biológiai folyamatok azonban az iPS-sejtek nyújtotta modellben tanulmányozhatóak a legbehatóbban, hiszen ez már a kóros folyamatok korai fázisának vizsgálatait is lehetôvé teszi. Az iPS-sejt-technológia hidat képez a post mortem szövettani vizsgálatok és az állatmodellek alkalmazása között, és kiterjeszti vizsgálati lehetőségeinket, az embrionális őssejtek etikai problémái nélkül. Problémát jelenthet a sejttenyésztés során fellépő spontán mutációk kialakulása, az epigenetikai tényezők megváltozása. Ezeken túl megállapítható, hogy az iPS-sejtek előállítása jelenleg 
alacsony hatékonysággal zajlik. Nem ismerjük a transzplantációt követően ezeknek a sejteknek a sorsát, valamint az indukált pluripotens őssejtek létrehozásához szükséges vektorok, transzpozonok beépülésének hoszszú távú következményeit. Mindezek ellenére a jövőben az iPS-sejtek nyújtotta modellnek egyre jelentősebb szerepe lehet a neurológiai betegségek hátterében álló molekuláris mechanizmus feltárásában.

Anyagi támogatás: A közlemény a Nemzeti Agykutatási Program (KTIA_NAP_13-1-2013-0001 és NAP-B KTIA_NAP_13-2014-0011) támogatásával készült.

Szerzői munkamegosztás: B. Z.: Feltárta és feldolgozta a közlemény témájához tartozó nemzetközi szakirodalmat, azt a tudományos közlemények esetén elvárt írásos formába rendezte. R. J., M. M. J.: Az adekvát következtetések levonásában, a szakmai nyelv alkalmazásában, a kézirat szakmai lektoraiként múködtek közre. A közlemény végleges változatát mindhárom szerző elolvasta és jóváhagyta.

Érdekeltségek: A szerzőknek nincsenek érdekeltségeik.

\section{Irodalom}

[1] Marchetto, M. C., Brennand, K. J., Boyer, L. F., et al.: Induced pluripotent stem cells (iPSCs) and neurological disease modeling: progress and promises. Hum. Mol. Genet., 2011, 20(R2), R109-R115.

[2] Cundiff, P. E., Anderson, S. A.: Impact of induced pluripotent stem cells on the study of central nervous system disease. Curr. Opin. Genet. Dev., 2011, 21(3), 354-361.

[3] Young, A. B.: Four decades of neurodegenerative disease research: how far we have come! J. Neurosci., 2009, 29(41), 12722-12728.

[4] Jucker, M.: The benefits and limitations of animal models for translational research in neurodegenerative diseases. Nat. Med., 2010, 16(11), 1210-1214.

[5] Wichterle, H., Przedborski, S.: What can pluripotent stem cells teach us about neurodegenerative diseases? Nat. Neurosci., 2010, 13(7), 800-804.

[6] Kola, I., Landis, J.: Can the pharmaceutical industry reduce attrition rates? Nat. Rev. Drug Discov., 2004, 3(8), 711-715.

[7] Takabashi, K., Yamanaka, S.: Induction of pluripotent stem cells from mouse embryonic and adult fibroblast cultures by defined factors. Cell, 2006, 126(4), 663-676.

[8] Takahashi, K., Tanabe, K., Ohnuki, M., et al.: Induction of pluripotent stem cells from adult human fibroblasts by defined factors. Cell, 2007, 131(5), 861-872.

[9] Denbam, M., Dottori, M.: Neural differentiation of induced pluripotent stem cells. Methods Mol. Biol., 2011, 793, 99-110.

[10] Mummery, C. L., Zhang, J., Ng, E. S., et al.: Differentiation of human embryonic stem cells and induced pluripotent stem cells to cardiomyocytes: a methods overview. Circ. Res., 2012, $111(3), 344-358$.

[11] Takahashi, K., Okita, K., Nakagawa, M., et al.: Induction of pluripotent stem cells from fibroblast cultures. Nat. Protoc., 2007, 2(12), 3081-3089.
[12] Chamberlain, S. J., Li, X. J., Lalande, M.: Induced pluripotent stem (iPS) cells as in vitro models of human neurogenetic disorders. Neurogenetics, 2008, 9(4), 227-235.

[13] Durnaoglu, S., Genc, S., Genc, K.: Patient-specific pluripotent stem cells in neurological diseases. Stem Cells Int., 2011, 2011, 212487.

[14] Ferri, C. P., Prince, M., Brayne, C., et al.: Global prevalence of dementia: a Delphi consensus study. Lancet, 2005, 366(9503), 2112-2117.

[15] Lunn, J. S., Sakowski, S. A., Hur, J., et al.: Stem cell technology for neurodegenerative diseases. Ann. Neurol., 2011, 70(3), 353361.

[16] Holm, S.: Time to reconsider stem cell ethics - the importance of induced pluripotent cells. J. Med. Ethics, 2008, 34(2), 63-64.

[17] Israel, M. A., Yuan, S. H., Bardy, C., et al.: Probing sporadic and familial Alzheimer's disease using induced pluripotent stem cells. Nature, 2012, 482(7384), 216-220.

[18] Peng, J., Liu, Q., Rao, M. S., et al.: Using human pluripotent stem cell-derived dopaminergic neurons to evaluate candidate Parkinson's disease therapeutic agents in MPP+ and rotenone models. J. Biomol. Screen., 2013, 18(5), 522-533.

[19] Ren, ., Jiang, $H ., H u, Z$., et al.: Parkin mutations reduce the complexity of neuronal processes in iPSC-derived human neurons. Stem Cells, 2015, 33(1), 68-78.

[20] An, M. C., Zhang, N., Scott, G., et al.: Genetic correction of Huntington's disease phenotypes in induced pluripotent stem cells. Cell Stem Cell, 2012, 11(2), 253-263.

[21] Amir, R. E., Van den Veyver, I. B., Wan, M., et al.: Rett syndrome is caused by mutations in X-linked MECP2, encoding methylCpG-binding protein 2. Nat. Genet., 1999, 23(2), 185-188.

[22] Marchetto, M. C., Carromeu, C., Acab, A., et al.: A model for neural development and treatment of Rett syndrome using human induced pluripotent stem cells. Cell, 2010, 143(4), 527539.

[23] Amenduni, M., De Filippis, R., Cheung, A. Y., et al.: iPS cells to model CDKL5-related disorders. Eur. J. Hum. Genet., 2011, 19(12), 1246-1255.

[24] Williams, E. C., Zhong, X., Mohamed, A., et al.: Mutant astrocytes differentiated from Rett syndrome patients-specific iPSCs have adverse effects on wild-type neurons. Hum. Mol. Genet., 2014, 23(11), 2968-2980.

[25] Santoro, M. R., Bray, S. M., Warren, S. T.: Molecular mechanisms of fragile X syndrome: a twenty-year perspective. Annu. Rev. Pathol., 2012, 7, 219-245.

[26] Urbach, A., Bar-Nur, O., Daley, G. Q., et al.: Differential modeling of fragile $\mathrm{X}$ syndrome by human embryonic stem cells and induced pluripotent stem cells. Cell Stem Cell, 2010, 6(5), 407411.

[27] Sheridan, S. D., Theriault, K. M., Reis, S. A., et al.: Epigenetic characterization of the FMRl gene and aberrant neurodevelopment in human induced pluripotent stem cell models of fragile $\mathrm{X}$ syndrome. PLoS ONE, 2011, 6(10), e26203.

[28] Patterson, D.: Molecular genetic analysis of Down syndrome. Hum. Genet., 2009, 126(1), 195-214.

[29] Shi, Y., Kirwan, P., Smith, J., et al.: A human stem cell model of early Alzheimer's disease pathology in Down syndrome. Sci. Transl. Med., 2012, 4(124), 124ra29.

[30] Hibaoui, Y., Grad, I., Letourneau, A., et al.: Modelling and rescuing neurodevelopmental defect of Down syndrome using in duced pluripotent stem cells from monozygotic twins discordant for trisomy 21. EMBO Mol. Med., 2014, 6(2), 259-277.

[31] Pasinelli, P., Brown, R. H.: Molecular biology of amyotrophic lateral sclerosis: insights from genetics. Nat. Rev. Neurosci., 2006, 7(9), 710-723.

[32] Liscic, R. M., Breljak, D.: Molecular basis of amyotrophic lateral sclerosis. Prog. Neuropsychopharmacol. Biol. Psychiatry, 2011, 35(2), 370-372. 
[33] Liu, X., Chen, J., Li, X., et al.: Generation of induced pluripotent stem cells from amyotrophic lateral sclerosis patientcarrying SODl-Vl4M mutation. Zhonghua Yi Xue Za Zhi, 2014, 94(27), 2143-2147.

[34] Mitne-Neto, M., Machado-Costa, M., Marchetto, M. C., et al.: Downregulation of VAPB expression in motor neurons derived from induced pluripotent stem cells of ALS8 patients. Hum. Mol. Genet., 2011, 20(18), 3642-3652.
[35] Bilican, B., Serio, A., Barmada, S. J., et al.: Mutant induced pluripotent stem cell lines recapitulate aspects of TDP-43 proteinopathies and reveal cell-specific vulnerability. Proc. Natl. Acad. Sci. U.S.A., 2012, 109(15), 5803-5808.

(Balogh Zoltán, Budapest, Vaskapu u. 10-14/B/506., 1097 e-mail: hun.balogh.zoltan@gmail.com)

\section{A rendezvények és kongresszusok híranyagának leadása}

a lap megjelenése előtt legalább 40 nappal lehetséges, a 6 hetes nyomdai átfutás miatt. Kérjük megrendelőink szíves megértését.

A híranyagokat a következő címre kérjük: Orvosi Hetilap titkársága: Budai.Edit@akkrt.hu Akadémiai Kiadó Zrt. 